Lia Amaliya, Robi Ardiansyah, Demi Nurdiyanti Fadilah, Muhamad Lutpi, Muhamad

Maulana Fahrudin, Muhammad Firmansyah, Muhammad Harbi Hanif, Oka Angsoka,

Rodhiyah Qona'ah, Ryan Gunawan, Teti Trisnawati, Via Novianti, Vuri Lestari

Oktaviani, Yanuar Arifin (Mahasiswa)

Vol. 3 No 1, Februari 2021

ISSN 2657-0203

e-ISSN 2686-0244

\title{
PROFIL DESA BERKELANJUTAN DI DESA NAGASARI
}

Lia Amaliya (Dosen), Robi Ardiansyah, Demi Nurdiyanti Fadilah, Muhamad Lutpi, Muhamad Maulana Fahrudin, Muhammad Firmansyah, Muhammad Harbi Hanif, Oka Angsoka, Rodhiyah Qona'ah, Ryan Gunawan, Teti Trisnawati, Via Novianti, Vuri Lestari Oktaviani, Yanuar Arifin (Mahasiswa)

Program Studi Ilmu Hukum, Fakultas Hukum

Universitas Buana Perjuangan Karawang

liaAmalia@ubpkarawang.ac.id

\begin{abstract}
ABSTRAK
Kelurahan atau Desa merupakan salah satu unsur kewilayahan terkecil di dalam Negara Kesatuan Republik Indonesia (NKRI). Walaupun demikian, Desa/Kelurahan mempunyai peran strategis dalam pencapaian sasaran pembangunan. Profil Desa merupakan gambaran menyeluruh tentang karakter desa yang meliputi Data Dasar Keluarga, Potensi Sumber daya Alam, Suber daya Manusia, Kelembagaan, Prasarana dan Sarana, serta Perkembangan Kemajuan \& Permasalahan yang dihadapi Kelurahan/desa. Data profil desa / kelurahan tersebut perlu didayagunakan untuk mendorong pertumbuhan perkembangan desa/kelurahan, sebagai proses perencanaan dalam menyusun program pembangunan dan kesejahteraan masyarakat. Kuliah Kerja Nyata (KKN) yang dilakukan Universita Buana Perjuangan Karawang di Kelurahan Nagasari Kabupaten Karawang Propinsi Jawa Barat yang mengusung tema "Profil Desa Untuk Tujuan Pembangunan Berkelanjutan" telah melakukan gambaran umum profil Desa/Kelurahan Nagasari meliputi Potensi Desa, Pedidikan, Kesehatan, Lapangan Kerja, keagamaan, industry kecil, Lembaga pemberdayaan masyarakat, pendapatan daerah, dan lain-lain, yang diharapkan potensi desa dapat diketahui oleh masayrakat umum dan terlebih dapat dikembangkan sebagai nilai lebih untuk desa.
\end{abstract}

\section{Kata Kunci: Desa/Keluarahan Nagasari, Profil Desa, Pembangunan Berkelanjutan}

\section{ABSTRACK}

Village is one of the smallest territorial elements in the Unitary State of the Republic of Indonesia (NKRI). However, the village has a strategic role in achieving development goals. The Village Profile is a comprehensive picture of the character of the village which includes Basic Family Data, Natural Resource Potential, Human Resources, Institutions, Infrastructure and Facilities, as well as the Development of Progress \& Problems facing the village. The village profile data needs to be utilized to encourage the growth of village development, as a planning process in formulating development programs and community welfare. Real Work Lecture (KKN) conducted by Universita Buana Perjuangan Karawang in Nagasari Village, Karawang Regency, West Java Province which carries the theme "Village Profile for Sustainable Development Goals" has carried out an overview of the Nagasari Village profile including Village Potential, Education, Health, Employment, Religion, small industry, community empowerment institutions, regional income, and others, it is hoped that the potential of the village can be known by the general public and moreover it can be developed as an added value for the village. 
Lia Amaliya, Robi Ardiansyah, Demi Nurdiyanti Fadilah, Muhamad Lutpi, Muhamad Maulana Fahrudin, Muhammad Firmansyah, Muhammad Harbi Hanif, Oka Angsoka, Rodhiyah Qona'ah, Ryan Gunawan, Teti Trisnawati, Via Novianti, Vuri Lestari Oktaviani, Yanuar Arifin (Mahasiswa)

Vol. 3 No 1, Februari 2021

ISSN 2657-0203 e-ISSN 2686-0244

Keywords: Nagasari Village, Village Profile, Sustainable Development

\section{PENDAHULUAN}

\subsection{Latar Belakang}

Desa yang maju serta penduduk yang makmur merupakan cita-cita masyarakat secara umum. Dalam mewujudkan hal tersebut, maka perlu diketahui potensi-potensi desa yang dapat digali serta dikembangkan. Sudah selayaknya di tingkat Desa/Kelurahan menjadi pusat aktifitas Pemerintahan, Pembangunan dan Pemberdayaan Masyarakat, termasuk juga penyusunan data dasar dalam mendukung berbagai aktifitas tersebut. Data yang valid dan akuntabel merupakan salah satu elemen penting dalam perencanaan pembangunan baik di tingkat pusat maupun pada tingkat daerah.

Profil Desa/Kelurahan adalah gambaran menyeluruh tentang karakter desa/kelurahan yang meliputi data dasar keluarga, potensi sumber daya alam, sumber daya manusia, kelembagaan, prasarana dan sarana serta perkembangan kemajuan dan permasalahan yang dihadapi desa dan kelurahan. ${ }^{1}$ Data profil desa/kelurahan tersebut perlu didayagunakan untuk mendorong pertumbuhan perkembangan desa/kelurahan, sebagai proses perencanaan dalam menyusun program pembangunan dan kesejahteraan masyarakat.

Adapun kegunaan/mafaat dari profil desa/kelurahan adalah memberikan gambaran menyeluruh tentang:

1. Karakter desa/kelurahan yang meliputi potensi sumber daya alam, sumber daya manusia, kelembagaan, sarana, serta perkembangan kemajuan dan permasalahan yang dihadapi desa/kelurahan.

2. Mengetahui gambaran potensi dan tingkat perkembangan desa/kelurahan yang akuran, komprehensif dan integral.

3. Sebagai dasar untuk menetapkan program kegiatan.

4. Penetapan Anggaran pembangunan.

Untuk mewujudkan fungsi profil Desa dan Kelurahan sebagai sumber informasi potensi desa dan kelurahan, Universitas Buana Perjuangan 
Lia Amaliya, Robi Ardiansyah, Demi Nurdiyanti Fadilah, Muhamad Lutpi, Muhamad Maulana Fahrudin, Muhammad Firmansyah, Muhammad Harbi Hanif, Oka Angsoka, Rodhiyah Qona'ah, Ryan Gunawan, Teti Trisnawati, Via Novianti, Vuri Lestari Oktaviani, Yanuar Arifin (Mahasiswa)

Vol. 3 No 1, Februari 2021

ISSN 2657-0203 e-ISSN 2686-0244

\section{1https://www.bppkpd.id/profil-desa/}

Karawang mengadakan Kuliah Kerja Nyata dengan tema "Profil Desa Untuk Tujuan Pembangunan Berkelanjutan”. Dengan diselenggarakannya Kuliah Kerja Nyata (KKN) dengan Tujuan Pembangunanan Berkelanjutan (TPB) diharapkan sebagai langkah awal untuk membangun sistem database profil desa sebagai perangkat untuk mempermudah update data jika terdapat perubahan sehingga data profil desa selalu terbaru dan realtime.

Kuliah Kerja Nyata adalah bentuk kegiatan pengabdian kepada masyarakat oleh mahasiswa dengan pendekatan lintas keilmuan dan sektoral pada waktu dan daerah tertentu di Indonesia sesuai dengan Tri Dharma Perguruan Tinggi yang harus dilakukan oleh setiap Perguruan Tinggi.

Desa/Kelurahan Nagasari adalah salah satu Kelurahan Kecamatan Karawang Barat Kabupaten Karawang Propinsi Jawa Barat. Kelurahan Nagasari merupakan dasar dari satuan pemerintahan terkecil dari suatu komunitas pemerintahan Negara. Sehingga boleh dikatakan bahwa keberhasilan dalam melakukan pembangunan juga tergantung dari sejauh mana partisipasi masyarakat beserta aparatur pemerintahan Kelurahan dalam perencanaan pembangunan tersebut.

\subsection{Tujuan}

Adapun tujuan dari kegiatan KKN online tahun 2020 ini adalah sebagai berikut:

\section{Tujuan Umum}

a) Melaksanakan amanat Undang-Undang Republik Indonesia yang terrefleksikanjuga dalam kurikulum di UBP Karawang

b) Membantu pemerintah dalam upaya pencegahan dan penanggulangan COVID-19 sesuai kemampuan dengan memberikan bantuan barangbarang yang diperlukan dalam upaya tersebut 
Lia Amaliya, Robi Ardiansyah, Demi Nurdiyanti Fadilah, Muhamad Lutpi, Muhamad Maulana Fahrudin, Muhammad Firmansyah, Muhammad Harbi Hanif, Oka Angsoka, Rodhiyah Qona'ah, Ryan Gunawan, Teti Trisnawati, Via Novianti, Vuri Lestari Oktaviani, Yanuar Arifin (Mahasiswa)

Vol. 3 No 1, Februari 2021

ISSN 2657-0203 e-ISSN 2686-0244

c) Mengenalkan mahasiswa tentang bagaimana kehidupan bermasyarakat, pentingnya sikap berempati dan peduli sesama, serta menjadi problem solver bagi berbagai macam masalah pembangunan masyarakat

d) Meningkatkan, memperluas dan mempererat hubungan baik antara universitas dengan pemerintah dan masyarakat sasaran

e) Membantu terwujudnya ketersediaan data yang dapat yang dapat digunakan untuk perencanaan pembangunan desa yang selaras dengan target Tujuan Pembangunan Berkelanjutan

f) Mendukung pemerintah dalam upaya mewujudkan Pencapaian Tujuan Pembangunan Berkelanjutan sesuai dengan Perpres No 59 Tahun

\section{Tujuan Khusus}

a) Membuat kajian profiling desa dan kelurahan yang memuat berbagai macam statistik desa, potensi, masalah yang dihadapi, dan lain-lain sehingga menjadi profil desa yang lengkap dengan rencana/rekomendasi pembangunan ke depan sesuai dengan agenda Tujuan Pembangunan Berkelanjutan

b) Sebagai langkah awal, untuk membangun sistem database profil desa dan kelurahansebagai perangkat untuk mempermudah update data jika terjadi perubahan sehingga data profil desa dan kelurahan selalu yang terbaru dan realtime

\subsection{Ruang Lingkup}

KKN online ini dibatasi pada hal-hal sebagai berikut:

1. Orientasi lingkungan kerja dan pengambilan data-data yang ada di Desa/kelurahan Pancawati untuk dijadikan penelitian.

2. Menganalisa potensi desa yang ada di kelurahan Pancawati berdasarkan data yang diperoleh dari questioner.

3. Pengembangan profil desa untuk pembangunan berkelanjutan.

\subsection{Manfaat}

Adapun manfaat secara umum yang terlibat dalam KKN online tahun 2020 ini adalah sebagai berikut: 
Lia Amaliya, Robi Ardiansyah, Demi Nurdiyanti Fadilah, Muhamad Lutpi, Muhamad Maulana Fahrudin, Muhammad Firmansyah, Muhammad Harbi Hanif, Oka Angsoka, Rodhiyah Qona'ah, Ryan Gunawan, Teti Trisnawati, Via Novianti, Vuri Lestari Oktaviani, Yanuar Arifin (Mahasiswa)

Vol. 3 No 1, Februari 2021

ISSN 2657-0203

e-ISSN 2686-0244

1. Bagi mahasiswa, untuk menerapkan ilmu teoritis yang telah didapatkan di bangku perkuliahan dengan cara mengkaji permasalahan dan potensi yang ada didesa sehingga dapat menjadi problem solver pada taraf hidup yang lebih baik.

2. Bagi Universitas, Kuliah Kerja Nyata $(\mathrm{KKN})$ adalah salah satu bentuk dari Tri Dharma Perguruan Tinggi yaitu pengabdian kepada masyarakat dengan melibatkan dosen dan mahasiswa sebagai media memperkenalkan Univerrsitas Buana Perjuangan Karawang.

3. Bagi Pemerintah, Kuliah Kerja Nyata $(\mathrm{KKN})$ dapat memberikan kajian profil desa yang meliputi potensi desa dan permasalahan di desa/masyarakat sehingga dapat menjadi rekomendasi pembangunan untuk kedepannya.

\section{METODE}

\subsection{Khalayak Sasaran Kegiatan}

Program Pengabdian Masyarakat ini dilaksanakan di Desa/Kelurahan Nagasari Kecamatan Karawang Barat Kabupaten Karawang dengan sasaran Masyarakat yang bertempat tinggal di Desa/Kelurahan Nagasari terkhusus aparat Desa.

\subsection{Metode Kegiatan}

Metode pelaksanaan kegiatan ini adalah dengan metode deskriftip yaitu menggambarkan profil desa/kelurahan Nagasari berkelanjutan dan wawancara dengan kepala Desa/kelurahan Nagasari dan Staff Desa,

\subsection{Langkah-langkah Kegiatan}

1. Mengajukan permohonan izin kepada pihak desa/kelurahan untuk melaksanakan Pengabdian.

2. Melakukan wawancara terkait profil dan perkembangan desa.

3. Memvalidasi hasil kuisioner yang di dapatkan dari staff desa/kelurahan kepada kepala desa/lurah Nagasari.

4. Menginput data profil desa yang didapatkan dari hasil pengabdian ke akun PRODESKEL. 
Lia Amaliya, Robi Ardiansyah, Demi Nurdiyanti Fadilah, Muhamad Lutpi, Muhamad Maulana Fahrudin, Muhammad Firmansyah, Muhammad Harbi Hanif, Oka Angsoka, Rodhiyah Qona'ah, Ryan Gunawan, Teti Trisnawati, Via Novianti, Vuri Lestari Oktaviani, Yanuar Arifin (Mahasiswa)

Vol. 3 No 1, Februari 2021

ISSN 2657-0203 e-ISSN 2686-0244

\section{HASIL DAN PEMBAHASAN}

Kelurahan Nagasari tempat dilaksanakannya program KKN ini adalah salah satu Kelurahan diantara 8 Kelurahan yang terdapat di wilayah Kecamatan Karawang Barat, dengan luas wilayah Kelurahan 325.400 Ha terdiri dari tanah darat.

Ketinggian rata-rata dari permukaan laut sekitar $25 \mathrm{~m}$ dan terletak pada daerah daratan, kondisi tersebut memberikan gambaran pengembangan wilayah perkotaan yang lebih besar, karena hambatan fisik yang ada relatif kecil.

Temperatur rata-rata di Kelurahan Nagasari 36 derajat Celcius, beriklim tropis dan mempunyai 2 (dua) musim kemarau dan musim hujan dengan curah hujan antara $3.000 \mathrm{~mm}$ sampai dengan $3.100 \mathrm{~mm}$.

Jarak dari Kelurahan Nagasari ke Kecamatan Karawang Barat sejauh 4 km dan jarak dari Kelurahan Nagasari ke Pemda Kabupaten Karawang dapat ditempuh dalam waktu 4 (empat) menit:

Batas wilayah Kelurahan Nagasari adalah sebagai berikut:

- Sebelah Utara

: Kelurahan Karangpawitan

- Sebelah Timur

: Kelurahan Karawang Wetan

- Sebelah Selatan

: Kelurahan Adiarsa Barat

- Sebelah Barat

: Kelurahan Karawang Kulon

\section{1) POTENSI DESA/ KELURAHAN}

\subsection{Luas Dan Pembagian Wilayah}

Luas wilayah Kelurahan Nagasari Kecamatan Karawang Baratmemiliki luas wilayah $325.400 \mathrm{Ha}$, yang terdiri dari tanah darat secara administratif terbagi dalam

- Rukun warga: 37 Rukun warga (RW)

- Rukun Tetangga: 114Rukun Tetangga (RT)

\subsection{Kependudukan}

Jumlah Penduduk seluruhnya adalah 17.121 jiwa dan 7.816 Kepala Keluarga (KK), yang terdiri dari:
- Laki-laki
: 8.864 Jiwa 
Lia Amaliya, Robi Ardiansyah, Demi Nurdiyanti Fadilah, Muhamad Lutpi, Muhamad Maulana Fahrudin, Muhammad Firmansyah, Muhammad Harbi Hanif, Oka Angsoka, Rodhiyah Qona'ah, Ryan Gunawan, Teti Trisnawati, Via Novianti, Vuri Lestari

Oktaviani, Yanuar Arifin (Mahasiswa)

Vol. 3 No 1, Februari 2021

ISSN 2657-0203

e-ISSN 2686-0244

- Perempuan $\quad: 8.257$ Jiwa

Table 1.1.2 Kependudukan

\begin{tabular}{|c|l|c|c|c|c|c|}
\hline \multirow{2}{*}{ No } & \multirow{2}{*}{ Lingkungan } & \multirow{2}{*}{ Jml } & Jml & \multicolumn{2}{|c|}{ Penduduk } & Jumlah \\
\cline { 3 - 7 } & & RW & RT & L & P & KK \\
\hline 1 & Krajan Barat (Gg.Bojong ) & 2 & 6 & 430 & 451 & 253 \\
\hline 2 & Krajan Timur & 2 & 6 & 541 & 483 & 337 \\
\hline 3 & Sadamalun I & 3 & 9 & 779 & 847 & 525 \\
\hline 4 & Sadamalun III & 3 & 7 & 703 & 689 & 398 \\
\hline 5 & Santiong Selatan & 3 & 8 & 374 & 333 & 241 \\
\hline 6 & Santiong Utara & 3 & 7 & 377 & 373 & 214 \\
\hline 7 & Babakan Cianjur & 5 & 15 & 1.227 & 1.31 & 751 \\
\hline 8 & Dipo & 3 & 9 & 646 & 643 & 687 \\
\hline 9 & Karang Anyar & 3 & 9 & 665 & 685 & 442 \\
\hline 10 & Kepuh & 3 & 10 & 1.631 & 1.059 & 2.7 \\
\hline 11 & Guro I & 1 & 6 & 554 & 562 & 474 \\
\hline 12 & Perum Green Garden & 5 & 19 & 937 & 822 & 859 \\
\hline 13 & Perum Bhakti Praja & 1 & 3 & & & \\
\hline & & 37 & 114 & 8.864 & 8.257 & 7.881 \\
\hline
\end{tabular}

\subsection{LAPANGAN KERJA}

Dari jumlah penduduk 17.121 jiwa, usia produktif yang merupakan angka kerja sebanyak 12.576 orang dengan lapangan kerja sebagai pegawai Negeri, Pegawai Swasta sebagian banyak yang bermata pencaharian sebagai pedagang dan buruh karena Kelurahan Nagasari merupakan daerah perkotaan.

\subsection{PENDIDIKAN}

Sarana/prasarana pendidikan formal, baik itu pendidikan umum maupun pendidikan keagamaan cukup memadai dengan harapan kwalitasnya pun meningkat hal ini sejalan dengan program pemerintah mengenai peningkatan kwalitas sumber daya manusia dan wajib belajar 9 tahun. 
Lia Amaliya, Robi Ardiansyah, Demi Nurdiyanti Fadilah, Muhamad Lutpi, Muhamad Maulana Fahrudin, Muhammad Firmansyah, Muhammad Harbi Hanif, Oka Angsoka, Rodhiyah Qona'ah, Ryan Gunawan, Teti Trisnawati, Via Novianti, Vuri Lestari Oktaviani, Yanuar Arifin (Mahasiswa)

Vol. 3 No 1, Februari 2021

ISSN 2657-0203 e-ISSN 2686-0244

Tabel 1.4 Pendidikan

\begin{tabular}{|c|l|c|c|c|c|}
\hline \multirow{2}{*}{ No } & \multicolumn{2}{|c|}{ Pendidikan } & Jml & Jml & Ket \\
\cline { 2 - 6 } & \multicolumn{1}{|c|}{ Tingkat } & Jumlah & Dosen & Murid & \\
\hline 1 & PAUD & 6 & 25 & 230 & \\
\hline 2 & TK & 9 & 9 & 200 & \\
\hline 3 & SD & 10 & 132 & 3804 & \\
\hline 4 & SLTP & 4 & 60 & 1871 & \\
\hline 5 & SMU/SMK & 3 & 39 & 1.496 & \\
\hline 6 & Perguruan Tinggi & - & - & - & - \\
\hline 7 & Madrasah & 10 & 8 & 240 & \\
\hline 8 & Tsanawiyah & - & - & - & - \\
\hline 9 & Pesantren & - & - & - & - \\
\hline
\end{tabular}

\subsection{PERTANIAN}

Sebagaimana telah kita ketahui bahwa di Kelurahan Nagasari terutama di lingkungan kepuh merupakan tempat lahan pertanian, dimana masyarakatnya mempunyai mata pencaharian dengan menanam padi di sawah dan berkebun, dan juga warga dilingkungan kepuh memanfaatkan pekarangan yang kosong dengan memelihara ternak untuk tambahan ekonomi keluarganya, adapun tanaman yang ditanam berupa tanaman palawija, sayuran dan buah-buahan (tanaman Tabulapot / Tabulakar).

\subsection{INDUSTRI KECIL PERDANGAN DAN JASA}

\subsubsection{Industri Kecil}

Sektor industri kecil merupakan salah satu bidang yang tidak kalah pentingnya dalam kehidupan perekonomian, industri kecil merupakan kegiatan usaha yang menyerap tenaga kerja dan tentunya akan mengurangi pengangguran, dengan adanya industri kecil maka kegiatan perekonomian, khususnya dilingkungan industri tersebut meningkat, dimana daya beli masyarakat untuk memenuhi kebutuhan hidup akan dapat dipenuhi sejalan dengan berkembangnya industri kecil, adapun industri kecil yang ada di Kelurahan Nagasari sbb : 
Lia Amaliya, Robi Ardiansyah, Demi Nurdiyanti Fadilah, Muhamad Lutpi, Muhamad Maulana Fahrudin, Muhammad Firmansyah, Muhammad Harbi Hanif, Oka Angsoka, Rodhiyah Qona'ah, Ryan Gunawan, Teti Trisnawati, Via Novianti, Vuri Lestari

Oktaviani, Yanuar Arifin (Mahasiswa)

Vol. 3 No 1, Februari 2021

ISSN 2657-0203 e-ISSN 2686-0244

Table 1.6.1 Industri Kecil Pedangan

\begin{tabular}{|c|l|c|l|}
\hline No & Jenis Industri Kecil & $\begin{array}{c}\text { Jumlah } \\
\text { Tenaga } \\
\text { kerja }\end{array}$ & \multicolumn{1}{|c|}{ Lokasi } \\
\hline 1 & Tahu & 12 & Kepuh Nagasari Rw. 36 \\
\hline 2 & Tahu & 10 & Kepuh Nagasari Rw.36 \\
\hline 3 & Roti Juwita & 10 & Jl. Pepaya Guro I Rt. 4/11 \\
\hline 4 & Tahu & 2 & Jl. Nagasari Rt.02/02 \\
\hline 5 & Minuman & 6 & Jl. Nagasari Rt.12/04 \\
\hline 5 & Kecap Cap kunci & 18 & Jl. Tuparev N0.134 \\
\hline 6 & Makanan / Roti Dewi & 46 & Jl. Dewi Sartika No. 26 \\
\hline 7 & Tempe & $\ldots$ & Lubang jaya Rt.02/036 \\
\hline 8 & Pabrik Kecap & $\ldots$ & Babakan Asem-Krajan Timur \\
\hline
\end{tabular}

\subsubsection{Jenis Usaha}

Sektor perdagangan dan jasa di Kelurahan Nagasari cukup dominan, warga banyak yang mempunyai mata pencaharian dengan berdagang, usaha berdagang berupa pertokoan yang besar sampai pedagang kaki lima, dan ada juga usaha jasa lainnya berupa perbengkelan kendaraan otomotif sampai pembuatan asesorisnya serta usaha lainnya karena letak kelurahan Nagasari yang merupakan daerah perkotaan, sehingga perekonomian dilingkungan Kelurahan Nagasari cukup subur (menjanjikan) dimana usaha perdagangan dan jasa banyak yang berhasil. 
Lia Amaliya, Robi Ardiansyah, Demi Nurdiyanti Fadilah, Muhamad Lutpi, Muhamad Maulana Fahrudin, Muhammad Firmansyah, Muhammad Harbi Hanif, Oka Angsoka, Rodhiyah Qona'ah, Ryan Gunawan, Teti Trisnawati, Via Novianti, Vuri Lestari

Oktaviani, Yanuar Arifin (Mahasiswa)

Vol. 3 No 1, Februari 2021

ISSN 2657-0203

e-ISSN 2686-0244

Tabel 1.6.2 Jenis Usaha

\begin{tabular}{|c|l|c|c|}
\hline No & \multicolumn{1}{|c|}{ Jenis Usaha } & Banyaknya & Ket \\
\hline 1 & Warung & 395 & \\
\hline 2 & Toko & 225 & \\
\hline 3 & Kios & 75 & \\
\hline 4 & Apotek & 24 & \\
\hline 5 & Bengkel & 17 & \\
\hline
\end{tabular}

\begin{tabular}{|c|l|c|c|}
6 & Furniture & 6 & \\
\hline 7 & Percetakan & 7 & \\
\hline 8 & Notaris & 12 & \\
\hline 9 & Wartel & 2 & \\
\hline 10 & Show Room / Dealer & 3 & \\
\hline 11 & Jasa pertukangan & 153 & \\
\hline 12 & Material & 5 & \\
\hline
\end{tabular}

\subsection{KEAGAMAAN}

Sebagaimana masyarakat di lingkungan kelurahan Nagasari kebanyakan Agamis, religius, dimana warganya dari semenjak anak-anak dididik oleh orang tuanya untuk sekolah agama/mengaji sebagai dasar untuk pendidikan akhlak ditingkat dini, dalam pengembangan pendidikan non formal tersebut tentunya perlu didukung dengan fasilitas sarana/prasarana, salah satunya adalah tempat peribadatan yaitu mushola dan mesjid, dengan adanya pembangunan mushola dan mesjid maka akan bertambahnya anakanak yang belajar ilmu agama yang berarti meningkatnya kwalitas, akan tetapi yang diharapkan kwalitasnya pun akan meningkat.

Tabel 1.7 Keagamaan

\begin{tabular}{|c|l|c|c|c|}
\hline No & $\begin{array}{c}\text { Jenis Sarana } \\
\text { Peribadatan }\end{array}$ & Jumlah & Pemeluk Agama & Ket \\
\hline 1 & Mesjid & 15 & Islam & \\
\hline 2 & Mushola & 32 & Islam & \\
\hline
\end{tabular}


Lia Amaliya, Robi Ardiansyah, Demi Nurdiyanti Fadilah, Muhamad Lutpi, Muhamad Maulana Fahrudin, Muhammad Firmansyah, Muhammad Harbi Hanif, Oka Angsoka, Rodhiyah Qona'ah, Ryan Gunawan, Teti Trisnawati, Via Novianti, Vuri Lestari

Oktaviani, Yanuar Arifin (Mahasiswa)

Vol. 3 No 1, Februari 2021

ISSN 2657-0203 e-ISSN 2686-0244

\begin{tabular}{|c|l|c|c|c|}
3 & Majlis Ta'lim & 21 & Islam & \\
\hline 4 & Gereja & 4 & Kristen & \\
\hline 5 & Vihara & 1 & Budha & \\
\hline 6 & Pura & - & Hindu & \\
\hline 7 & Klenteng & - & Budha & \\
\hline
\end{tabular}

\subsection{KESEHATAN}

\subsubsection{Sarana dan Prasana}

Upaya peningkatan sumber daya manusia dan pemerataan kesejahteraan rakyat dibidang kesehatan, maka pembangunan dibidang kesehatan mendapat perhatian yang lebih besar.

Pelayanan Kesehatan bagi Masyarakat yang tidak mampu dilaksanakan melalui pelayanan jamkesmas, jumlah jamkesmas Kelurahan Nagasari sebanyak 2.614 Orang, dan disamping itu bagi masyarakat yang tidak mampu tetapi yang bersangkutan tidak terdaftar dalam jamkesmas maka akan mendapat pelayanan melalui Jamkesda, jumlah Jamkesda Kelurahan Nagasari sebanyak 5.112 Orang.

Tabel 1.8.1 Sarana dan Prasarana Kesehatan

\begin{tabular}{|c|l|c|c|}
\hline No & \multicolumn{1}{|c|}{ Jenis Layanan Kesehatan } & Jumlah & Ket \\
\hline 1 & Puskesmas & 1 & \\
\hline 2 & Puskesmas pembantu & 0 & \\
\hline 3 & Polikklinik / balai pengobatan & 2 & \\
\hline 4 & Posyandu & 21 & \\
\hline 5 & Dokter Praktek & 4 & \\
\hline 6 & Bidan Praktek & 7 & \\
\hline 7 & Rumah Sakit Swasta & 2 & \\
\hline 8 & Mantri Kesehatan Praktek & 1 & \\
\hline 9 & Dukun Paraji & 0 & \\
\hline 10 & Kader Posyandu & 105 & \\
\hline
\end{tabular}

\subsubsection{Keluarga Berencana (KB)}


Lia Amaliya, Robi Ardiansyah, Demi Nurdiyanti Fadilah, Muhamad Lutpi, Muhamad Maulana Fahrudin, Muhammad Firmansyah, Muhammad Harbi Hanif, Oka Angsoka, Rodhiyah Qona'ah, Ryan Gunawan, Teti Trisnawati, Via Novianti, Vuri Lestari

Oktaviani, Yanuar Arifin (Mahasiswa)

Vol. 3 No 1, Februari 2021

ISSN 2657-0203

e-ISSN 2686-0244

Untuk pengendalian pertumbuhan dan upaya terwujudnya NKKBS

(Norma Keluarga Kecil Bahagia sejahtera) maka Program Keluarga Berencana (KB) harus terus mendapat perhatian Khusus, disamping semakin meningkatnya laju pertumbuhan penduduk tiap tahun, dengan kategori sebagai berikut:

Jumlah Pasangan usia Subur (PUS) : 3978 Orang

Jumlah Akseptor KB Aktif (CU) : 3.833 Orang

Adapun sasaran yang diperoleh / dicapai dalam Program Keluarga Berencana $(\mathrm{KB})$ adalah:

Tabel 1.8.2 Keluarga Berencana (KB)

\begin{tabular}{|c|l|c|c|}
\hline NO & \multicolumn{1}{|c|}{ JENIS KB } & $\begin{array}{c}\text { JUMLAH } \\
\text { PENGGUNA }\end{array}$ & KET \\
\hline 1 & MOP & 13 & \\
\hline 2 & MOW & 138 & \\
\hline 3 & IUD & 309 & \\
\hline 4 & Implant & 77 & \\
\hline 5 & Suntik & 1.886 & \\
\hline 6 & Pil & 364 & \\
\hline 7 & Kondom & 46 & \\
\hline
\end{tabular}

\subsection{PEMBERDAYAAN KESEJAHTERAAN KELUARGA}

Perpanjangan tangan dari pemerintah dalam membantu mensejahterakan masyarakat, bahwa $40 \%$ dari hasil yang dicapai dalam mensejahterakan masyarakat Kelurahan Nagasari adalah berkat peran kader PKK. Kegiatan-kegiatannya antara lain:

1) Memasyarakatkan Kegiatan Posyandu

2) Memanfaatkan pekarangan untuk tanaman obat keloarga (Toga)

3) Warung Hidup dan peternakan / Perikanan

4) Menyalurkan dana dalam rangka kegiatan-kegiatan PKK

5) Memasyarakatkan Undang-undang perkawinan dan KDRT 
Lia Amaliya, Robi Ardiansyah, Demi Nurdiyanti Fadilah, Muhamad Lutpi, Muhamad Maulana Fahrudin, Muhammad Firmansyah, Muhammad Harbi Hanif, Oka Angsoka, Rodhiyah Qona'ah, Ryan Gunawan, Teti Trisnawati, Via Novianti, Vuri Lestari Oktaviani, Yanuar Arifin (Mahasiswa)

Vol. 3 No 1, Februari 2021

ISSN 2657-0203 e-ISSN 2686-0244

6) Memasyarakatkan gerakan hidup bersih melalui kegiatan K-3 lingkungan

7) Menyelenggarakan pengajian rutin melalui Majlis Ta'lim Kelurahan

\subsection{LEMBAGA PEMBERDAYAAN MASYARAKAT (LPM)}

Sebagai wadah forum konsultasi dan komunikasi, peranan Lembaga Pemberdayaan Masyarakat (LPM) Kelurahan Nagasari mempunyai kontribusi yang cukup baik dalam proses pembangunan yang dilaksanakan

di Kelurahan Nagasari. Hal ini, sejalan dengan perkembangan pembangunan yang pesat yang menuntut peran masyarakat di segala bidang. Dengan adanya LPM maka Masyarakat akan ikut berpartisipasi melaksanakan kegiatan melalui program kerja LPM, kepengurusan LPM terdapat seksi-seksi yang akan turun ke lapangan, seksi tersebut antara lain yaitu: Seksi Pembangunan, Seksi Kepemudaan, Seksi Pendidikan, Seksi Sosial, Seksi Keagamaan, Seksi Ekonomi dan Seksi Peranan Wanita.

\subsection{PENDAPATAN DAERAH}

Untuk meningkatkan Pendapatan Asli Daerah ( PAD ) Kelurahan Nagasari telah ada dan terus melaksanakan penyuluhan kepada masyarakat mengenai perzinan, pajak tontonan / izin rame-rame, dan lain sebagainya yang merupakan hasil dari pendapatan Asli Daerah, dan merupakan paling dominan dari hasil Pendapatan Asli Daerah ( PAD ) adalah pajak Bumi dan Bangunan ( PBB ), karena pemasukan / realisasi Pajak Bumi Bangunan mempunyai sumbangsih yang cukup besar dalam rangka membiayai penyelenggaraan pemerintah, pembangunan dan kegiatan kemasyarakatan di Kabupaten Karawang.

Tabel 1.11 Pendapatan Daerah

\begin{tabular}{|c|c|c|c|c|}
\hline No & Tahun & Target (Rp) & Realisasi (Rp) & Persentase \\
\hline 1 & 2015 & 903.748 .664 & 543.436 .054 & $60.13 \%$ \\
\hline 2 & 2016 & 957.210 .137 & 562.707 .001 & $58.80 \%$ \\
\hline
\end{tabular}


Lia Amaliya, Robi Ardiansyah, Demi Nurdiyanti Fadilah, Muhamad Lutpi, Muhamad Maulana Fahrudin, Muhammad Firmansyah, Muhammad Harbi Hanif, Oka Angsoka, Rodhiyah Qona'ah, Ryan Gunawan, Teti Trisnawati, Via Novianti, Vuri Lestari

Oktaviani, Yanuar Arifin (Mahasiswa)

Vol. 3 No 1, Februari 2021

ISSN 2657-0203

e-ISSN 2686-0244

\begin{tabular}{|c|c|c|c|c|}
\hline 3 & 2017 & 659.012 .627 & 297.410 .162 & $52 \%$ \\
\hline 4 & 2018 & 900.579 .735 & 474.704 .940 & $52,7 \%$ \\
\hline 5 & 2019 & & & $\%$ \\
\hline
\end{tabular}

Dari data yang kami sajikan diatas, khususnya mengenai data potensi Kelurahan Nagasari, dapat dikatakan:

a. Tingkat partisipasi masyarakat dalam pembiayaan pembangunan yang bersumber dari swadaya masyarakat cukup tinggi.

b. Kondisi Kelurahan Nagasari dimungkinkan untuk dikembangkan pada sector perdagangan, Jasa Trasportasi, Perbengkelan kendaraan dan Penginapan.

c. Kesadaran masyarakat dalam membayar PBB cukup tinggi, dengan dibantu setiap tahunnya Kelurahan Nagasari selalu berusaha mendekati target PBB.

d. Kelurahan antar umat beragama cukup harmonis. 
Lia Amaliya, Robi Ardiansyah, Demi Nurdiyanti Fadilah, Muhamad Lutpi, Muhamad Maulana Fahrudin, Muhammad Firmansyah, Muhammad Harbi Hanif, Oka Angsoka, Rodhiyah Qona'ah, Ryan Gunawan, Teti Trisnawati, Via Novianti, Vuri Lestari Oktaviani, Yanuar Arifin (Mahasiswa)

Vol. 3 No 1, Februari 2021

ISSN 2657-0203 e-ISSN 2686-0244

\section{2) PERKEMBANGAN DESA/KELURAHAN}

Tabel 2 Perkembangan Desa/Kelurahan

\begin{tabular}{|c|c|c|c|}
\hline JENIS POTENSI & & 2018 & 2020 \\
\hline Potensi Sumber Daya Alam & $\begin{array}{l}\text { Luas Tanah } \\
\text { Sawah }\end{array}$ & $181 \mathrm{Ha}$ & $181 \mathrm{Ha}$ \\
\hline $\begin{array}{l}\text { Potensi Sumber Daya } \\
\text { Manusia }\end{array}$ & $\begin{array}{c}\text { Jumlah } \\
\text { Penduduk }\end{array}$ & 18.721 Jiwa & 23.270 Jiwa \\
\hline $\begin{array}{l}\text { Potensi Kelembagaan dan } \\
\text { Ekonomi }\end{array}$ & $\begin{array}{c}\text { Jumlah } \\
\text { Indusrtri Kecil } \\
\text { Menengah } \\
\end{array}$ & 11 Unit & 18 Unit \\
\hline \multirow{6}{*}{$\begin{array}{l}\text { Potensi Sarana dan } \\
\text { Prasarana }\end{array}$} & & $\begin{array}{c}\text { Prasarana } \\
\text { Kesehatan : }\end{array}$ & $\begin{array}{c}\text { Prasarana } \\
\text { Kesehatan : }\end{array}$ \\
\hline & & $\begin{array}{l}\text { Apotek : } 14 \\
\text { Unit }\end{array}$ & $\begin{array}{l}\text { Apotek : } 22 \\
\text { Unit }\end{array}$ \\
\hline & & $\begin{array}{l}\text { Rumah } \\
\text { Bersalin : } 1 \\
\text { Unit } \\
\end{array}$ & $\begin{array}{l}\text { Rumah } \\
\text { Bersalin : } 2 \\
\text { Unit } \\
\end{array}$ \\
\hline & & $\begin{array}{l}\text { Prasarana } \\
\text { Kebersihan }\end{array}$ & $\begin{array}{l}\text { Prasarana } \\
\text { Kebersihan }\end{array}$ \\
\hline & & $\begin{array}{l}\text { Gerobak } \\
\text { sampah : } 5 \\
\text { unit } \\
\end{array}$ & $\begin{array}{l}\text { Gerobak } \\
\text { sampah : } 37 \\
\text { unit } \\
\end{array}$ \\
\hline & & $\begin{array}{l}\text { Tong sampah } \\
: 30 \text { Unit }\end{array}$ & $\begin{array}{l}\text { Tong sampah } \\
: 114 \text { Unit }\end{array}$ \\
\hline
\end{tabular}


Lia Amaliya, Robi Ardiansyah, Demi Nurdiyanti Fadilah, Muhamad Lutpi, Muhamad Maulana Fahrudin, Muhammad Firmansyah, Muhammad Harbi Hanif, Oka Angsoka, Rodhiyah Qona'ah, Ryan Gunawan, Teti Trisnawati, Via Novianti, Vuri Lestari

Oktaviani, Yanuar Arifin (Mahasiswa)

Vol. 3 No 1, Februari 2021

ISSN 2657-0203

e-ISSN 2686-0244

Dari data berikut dapat dilihat perkembangan di Kelurahan nagasari meliputi potensi sumber daya manusia, potensi kelembagaan dan ekonomi, dan potensi sarana dan prasarana di tahun 2018 dibandingkan dengan 2020 memiliki perkembangan. Untuk potensi seumber daya alam di tahun tersebut sampai sekarang belum mengalami perkembangan.

\section{3) KETERCAPAIAN TUJUAN PEMBANGUNAN BERKELANJUTAN (TPB)}

Tabel 3

Ketercapaian tujuan pembangunan berkelanjutan

\begin{tabular}{|c|c|c|c|}
\hline No & $\begin{array}{c}\text { Tujuan Pembangunan } \\
\text { Berkelanjutan }\end{array}$ & Ketercapaian & Keterangan \\
\hline 1 & Tanpa Kemiskinan & Tercapai & $\begin{array}{l}\text { Tercapainya target } 100 \% \text { dalam } \\
\text { pembayaran pajak. }\end{array}$ \\
\hline 2 & Tanpa Kelaparan & Tercapai & $\begin{array}{l}\text { Angka Balita bergizi baik lebih } \\
\text { dari } 95 \% \text {. }\end{array}$ \\
\hline 3 & $\begin{array}{l}\text { Kehidupan sehat dan } \\
\text { sejahtera }\end{array}$ & Tercapai & $\begin{array}{l}\text { Angka Kematian Bayi kurang } \\
\text { dari0,1\% dalam } 1 \text { tahun. }\end{array}$ \\
\hline 4 & Pendidikan berkualitas & Tercapai & $\begin{array}{l}\text { Akreditasi sekolah di nagasari } \\
\text { rata-rata A. }\end{array}$ \\
\hline 5 & Kesetaraan gender & Tercapai & $\begin{array}{l}\text { Terdapatnya perempuan dalam } \\
\text { berbagai profesi. }\end{array}$ \\
\hline 6 & $\begin{array}{l}\text { Air Bersih dan Sanitasi } \\
\text { Layak }\end{array}$ & Tercapai. & $\begin{array}{l}\text { Tidak adanya pemakaian air } \\
\text { sungai dan sumur sebagai } \\
\text { sumber air. }\end{array}$ \\
\hline 7 & $\begin{array}{l}\text { Energi Bersih dan } \\
\text { Terjangkau }\end{array}$ & Tercapai & $\begin{array}{l}\text { Meratanya listrik di semua } \\
\text { wilayah nagasari. }\end{array}$ \\
\hline 8 & $\begin{array}{l}\text { Pekerjaan layak dan } \\
\text { pertumbuhan ekonomi. }\end{array}$ & Tercapai & $\begin{array}{l}\text { Kewajiban Upah pekerja untuk } \\
\text { mengikuti UMR. }\end{array}$ \\
\hline 9 & $\begin{array}{l}\text { Industri, Inovasi dan } \\
\text { Infrastruktur. }\end{array}$ & Tercapai & $\begin{array}{l}\text { Terdapatnya industri kecil } \\
\text { menengah yang memproduksi } \\
\text { produk hasil pangan. }\end{array}$ \\
\hline
\end{tabular}


Lia Amaliya, Robi Ardiansyah, Demi Nurdiyanti Fadilah, Muhamad Lutpi, Muhamad

Maulana Fahrudin, Muhammad Firmansyah, Muhammad Harbi Hanif, Oka Angsoka,

Rodhiyah Qona'ah, Ryan Gunawan, Teti Trisnawati, Via Novianti, Vuri Lestari

Oktaviani, Yanuar Arifin (Mahasiswa)

Vol. 3 No 1, Februari 2021

ISSN 2657-0203

e-ISSN 2686-0244

\begin{tabular}{|c|c|c|c|}
\hline 10 & $\begin{array}{l}\text { Berkurangnya } \\
\text { kesenjangan }\end{array}$ & Tercapai & $\begin{array}{l}\text { Terdapatnya bantuan kepada } \\
\text { warga yang kekurangan dari } \\
\text { warga setempat. }\end{array}$ \\
\hline 11 & $\begin{array}{l}\text { Kota dan komunitas } \\
\text { berkelanjutan. }\end{array}$ & Tercapai & \begin{tabular}{llr} 
Dengan & \multicolumn{2}{c}{ pembangunan } \\
infrastruktur & yang & selalu \\
ditingkatkan. & &
\end{tabular} \\
\hline 12 & $\begin{array}{l}\text { Konsumsi dan produksi } \\
\text { yang } \quad \text { bertanggung } \\
\text { jawab. }\end{array}$ & Tercapai & $\begin{array}{l}\text { Pengelolaan limbah industri dan } \\
\text { bahan kimia di kelurahan } \\
\text { nagasari. }\end{array}$ \\
\hline 15 & Ekosistem daratan. & Tercapai & $\begin{array}{l}\text { memanfaatkan pekarangan yang } \\
\text { kosong dengan memelihara } \\
\text { ternak untuk tambahan ekonomi } \\
\text { keluarganya }\end{array}$ \\
\hline 14 & $\begin{array}{l}\text { Perdamaian, keadilan } \\
\text { dan kelembagaan yang } \\
\text { tangguh. }\end{array}$ & Tercapai & \begin{tabular}{llr} 
Terdapatnya & \multicolumn{2}{c}{ Polsek dan } \\
BABINSA & serta & Mekanisme \\
Siskamling & &
\end{tabular} \\
\hline
\end{tabular}

\section{4) PERMASALAHAN DAN SOLUSI}

Hasil data yang telah didapatkan ditemukan kenaikan jumlah penduduk dari tahun 2017 ke 2020. Jumlah penduduk laki laki pada tahun 2019 meningkat $22,74 \%$ dari tahun 2017, kemudian pada tahun 2020 meningkat 1,09\% dari tahun 2019 dan jumlah penduduk perempuan pada tahun 2019 meningkat 29,78\% dari 2017, kemudian pada tahun 2020 jumlah penduduk perempuan meningkat 1,09\% dari tahun 2019.

Keadaan sektor ekonomi saat ini yang sedang terdampak oleh COVID-19 di mana terdapat banyak penurunan pendapatan pada sektor jasa dan industri sehingga banyak usaha yang gulung tikar. Tutupnya usaha-usaha tersebut meningkatkan jumlah pengangguran di masyarakat. Hal ini mengakibatkan penurunan pendapatan pada bidang perindustrian maupun jasa, sehingga membuat usaha masyarakat tidak sejahtera. Dengan demikian, peningkatkan jumlah pengangguran di masyarakat tidak dapat dihindari. Hal tersebut 
Lia Amaliya, Robi Ardiansyah, Demi Nurdiyanti Fadilah, Muhamad Lutpi, Muhamad Maulana Fahrudin, Muhammad Firmansyah, Muhammad Harbi Hanif, Oka Angsoka, Rodhiyah Qona'ah, Ryan Gunawan, Teti Trisnawati, Via Novianti, Vuri Lestari Oktaviani, Yanuar Arifin (Mahasiswa)

Vol. 3 No 1, Februari 2021

ISSN 2657-0203 e-ISSN 2686-0244

mendorong beberapa oknum melakukan kriminalitas yang berdalih untuk memenuhi kebutuhan ekonomi keluarga.

Hasil data yang didapatkan terdapat peningatan sejumlah kasus kriminalitas yang terbagi dalam beberapa jenis kejahatan, yaitu konflik perkelahian tahun ini sebanyak 5 kasus sedangkan pada tahun sebelumnya tercatat 0 kasus, pencurian tahun ini sebanyak 90 kasus sedangkan pada tahun sebelumnya tercatat 5 kasus, penipuan atau penggelapan tahun ini sebanyak 64 kasus sedangkan pada tahun sebelumnya 7 kasus.

Untuk mengendalikan situasi keamanan, ketentraman dan ketertiban yang kondusif, dilakukan upaya meliputi:

1) Upaya preventif, yaitu melalui mekanisme siskamling dan melakukan pemantauan kegiatan warga yang patut di duga memiliki potensi yang kiranya menimbulkan penyakit masyarakat seperti perjudian, penyalahgunaan obat psikotoprika dan minum-minuman keras yang memabukkan.

2) Upaya representatif, yaitu melalui tindakan hukum terhadap para pelanggar dengan menyerahkan ke pihak kepolisian untuk diprises lebih lanjut.

\section{5) PENGEMBANGAN POTENSI DESA}

Potensi adalah kemampuan yang mempunyai kemungkinan untuk dikembangkan. Begitu banyak potensi pada kelurahan nagasari, salah satunya adalah pada proses pengolahan sampah. Dengan jumlah penduduk yang banyak dapat di perkirakan sampah yang di hasilkan oleh warga perharinya terhitung banyak.

Pengelolaan sampah merupakan kegiatan yang sistematis, menyeluruh dan berkesinambungan yang meliputi pengurangan dan penanganan sampah. Maka dari itu pengolahan sampah merupakan salah satu potensi yang dapat dikembangkan. Dengan cara memisahkan sampah organik dan anorganik. Sampah organik dapat diolah menjadi kompos atau pupuk untuk tanaman. Dari sekian jenis sampah, yang paling krusial hingga menjadi perhatian dunia adalah sampah plastik, kecenderungan orang menggunakan plastik. Pemanfaatan sampah plastik pada sektor kerajinan juga dapat membantu meningkatkan ekonomi masyarakat. Pengelolaan sampah perlu 
Lia Amaliya, Robi Ardiansyah, Demi Nurdiyanti Fadilah, Muhamad Lutpi, Muhamad Maulana Fahrudin, Muhammad Firmansyah, Muhammad Harbi Hanif, Oka Angsoka, Rodhiyah Qona'ah, Ryan Gunawan, Teti Trisnawati, Via Novianti, Vuri Lestari Oktaviani, Yanuar Arifin (Mahasiswa)

Vol. 3 No 1, Februari 2021

ISSN 2657-0203 e-ISSN 2686-0244

dilakukan secara komprehensif dan terpadu dari hulu ke hilir agar memberikan manfaat secara ekonomi, sehat bagi masyarakat dan aman bagi lingkungan serta dapat mengubah perilaku masyarakat.

Potensi kelurahan selanjutnya dapa dilihat dari Jumlah penduduk kelurahan nagasari yang memiliki hak pilih sebanyak 16.001 dan dengan tingkat penggunaan hak pilih sebesar 100\%. Target Pajak Bumi dan Bangunan (PBB) sejumlah Rp.1.000.000.000,- (satu miliar rupiah) dan teralisasikan 100\% warga taat akan pajak. Maka secara psikologis warga Kelurahan Nagasari dapat menerapkan perilaku bekerja sama dengan baik.

\section{KESIMPULAN DAN REKOMENDASI}

\subsection{Kesimpulan}

Dari kegiatan Kuliah Kerja Nyata Online yang telah dilakukan di Kelurahan Nagasari dapat disimpulkan:

1. Jumlah penduduk laki laki pada tahun 2019 meningkat $22,74 \%$ dari tahun 2017, kemudian pada tahun 2020 meningkat 1,09\% dari tahun 2019 dan jumlah penduduk perempuan pada tahun 2019 meningkat 29,78\% dari 2017, kemudian pada tahun 2020 jumlah penduduk perempuan meningkat 1,09\% dari tahun 2019 .

2. Terdapat $31 \%$ penduduk yang telah menikah yang tercatat tidak memakai Kontrasepsi.

3. Jumlah konflik perkelahian tahun ini sebanyak 5 kasus sedangkan pada tahun sebelumnya tercatat 0 kasus, pencurian tahun ini sebanyak 90 kasus sedangkan pada tahun sebelumnya tercatat 5 kasus, penipuan atau penggelapan tahun ini sebanyak 64 kasus sedangkan pada tahun sebelumnya 7 kasus.

4. Kelurahan Nagasari memiliki $100 \%$ jumlah warga yang menaati pajak, hasil dari peningkatan yang konsisten bertahap setiap tahunnya. 
Lia Amaliya, Robi Ardiansyah, Demi Nurdiyanti Fadilah, Muhamad Lutpi, Muhamad Maulana Fahrudin, Muhammad Firmansyah, Muhammad Harbi Hanif, Oka Angsoka, Rodhiyah Qona'ah, Ryan Gunawan, Teti Trisnawati, Via Novianti, Vuri Lestari Oktaviani, Yanuar Arifin (Mahasiswa)

Vol. 3 No 1, Februari 2021

ISSN 2657-0203

\subsection{Rekomendasi}

e-ISSN 2686-0244

1. Disarankan unuk melakukan penyuluhan tentang pengolahan sampah rumah tangga untuk mengurangi biaya pengangkutan sampah serta untuk dimanfaatkan menjadi sektor kerajinan.

2 Perlunya Pembentukan BLK (Balai Latihan Kerja) di Kelurahan Nagasari khusus untuk Domisili Kelurahan Nagasari, dan Bekerja Sama Dengan Industri Kecil dan Usaha-usaha lainnya yang ada di Kelurahaan Nagasari merekomendasikan tenaga kerja masyarakat Kelurahan Nagasari.

3 Disarankan Kelurahan Nagasari Bekerja Sama Dengan Industri Kecil dan Usaha-usaha lainnya yang ada di Kelurahaan Nagasari untuk merekomendasikan tenaga kerja masyarakat Kelurahan Nagasari.

4 Disarankan untuk para tenaga pengajar dapat memanfaatkan media dan cara yang tepat untuk meningkatkan ketertarikan siswa dalam mengikuti Kegiatan Pembelajaran secara daring, yang tentunya diharapkan dapat secara tidak langsung juga meningkatkan tingkat pemahaman dan hasil belajar siswa.

5 Disarankan untuk meningkatkan pengendalian keamanan, ketentraman dan ketertiban melalui upaya preventif dan respresentatif.

\section{DAFTAR PUSTAKA}

Ade Sukardi. 2019. Laporan Tahunan Kelurahan Nagasari Tahun 2019. Karawang https://www.bppkpd.id/profil-desa/

wawancara kepala desa dan staf desa/kelurahan Nagasari 